\title{
Research on the Development Mode of Logistics Financial Services :Take Ningbo City for Example
}

\author{
Xiaowei Yang \\ Business and Trade School \\ Ningbo City College of Vocational Technology \\ Ningbo, PR.China \\ yangxiaowei@nbcc.cn
}

\author{
Jianjun $\mathrm{Xu}$ \\ Department of Economy \\ Institute of Science and Technology Ningbo University \\ Ningbo, PR.China \\ xu-jj@hotmail.com
}

\begin{abstract}
The logistic finance is the important component supporting factor of modern logistics, which represents one of the most important development direction of value-added in logistics industry. This paper firstly analyzes vital significance and theoretical foundation of the development of modern logistics financial services, then takes Ningbo City as an example and explains the comparative advantages of Ningbo City for the development of logistics financial services from the perspective of owning the Ningbo Port, favorable logistics industry, good financial environment. Next, some feasible development modes of logistics financial services in Ningbo City are put forward. At last, this paper points out some good countermeasures for the development of modern logistics financial services in Ningbo City.
\end{abstract}

Keywords-Logistics financial services; development mode; Ningbo city

\section{INTRODUCTION}

The combination of logistics and financial services is one of the vital means to outdo the competitor in the fierce market competition both for the current third-party logistics companies and the financial institutions. Logistics financial services means that the third-party logistics companies and financial institutions together provide clients with a series services including financing, clearing, funds transfer, information search and other services in the process of logistics supply chain management (Qiong Wu, 2005) ${ }^{[1]}$. The logistics industry needing for financial service support of Ningbo City, China, as one of the port and open cities, has not been met. Therefore, it's necessary to further study on the feasible development mode for modern logistics financial services to support for the development logistics industry.

\section{THE VIT AL SIGNIFICANCE OF THE DEVELOPMENT OF LOGIST ICS FINANCIAL SERVICES}

A. The development of logistics financial services may ease the needs of small and medium enterprises financing constraints.

Since reform and opening, a large number of small and medium enterprises emerged, which needs credit support for their development, but due to financial institutions only concerns about the risks of asymmetric information, so they cautiously select the lending enterprises, which brings out funds supply shortfall for a large number of small and medium enterprises. The development of logistics financial services may bring out the new financing channels for small and medium enterprises with the shortage of funds.

B. The development of logistics finance may meet the needs of the rapid development of modern logistics industry.

The third-party logistics enterprises facing the fierce competition must continue to carry out business innovation, and introduction of financial services on the basis of the offering logistics and information services. For the thirdparty logistics enterprises, the development of logistics financial services cannot only ease the financial constraints of logistics enterprises themselves, but also can get the competitive advantage of the logistics companies by offering logistic financial services.

C. The development of logistics financial services may meet the needs of payoff of financial institutions.

The development of logistics financial services may expand banking revenue and improve profit margins of banks. More important point is that, with the development of logistics financial services, this business pattern may bring the banks about a number of high-quality clients coming from small and medium enterprises, which will change the status quo of banks only relying on the VIP clients. 


\section{THE THEORETICAL BASIS OF THE DEVELOPMENT OF LOGISTICS FIINANCE}

\section{A. Supplychain management theory perspective}

The development of logistics financial services may help to carry out close and effective cooperation among the banks, the third-party logistics companies and customers in the supply chain system, and may improve the overall efficiency of logistics, trading efficiency of commodities. Logistics financial services may overcome the traditional limitations of a single company, standing on the height of the global supply chain, and provide financial services to meet the financing needs of small and medium enterprises small and medium enterprises, while extends the depth of banking services (Yihui Jiang, 2008) ${ }^{[2]}$. In addition, the development of logistics financial services may reduce the risks of information transmission, logistics distribution and supervision.

\section{B. The principal-agent theory perspective}

The logistics financial business is composite of a series of principal-agent relationships. In traditional bank lending patterns, the banks are the position of the principal, s mall and medium enterprises act as agents, there exists serious information asymmetry and moral hazard between the two parties, which causes financing difficulties for a number of small and medium enterprises. If carrying out logistics financial business, banks and enterprises can effectively alleviate the degree of information asymmetry between them. On the one hand, because of traditional loan mode by adding a third-party logistics companies, which are responsible for the supervision and management of the goods. On the other hand, the third-party logistics companies as agents of banks, may provide the banks with the information of clients to help bank monitoring and control credit risk, so logistics financial services may effectively reduce the risk of banks and promote the development of logistics.

\section{The transaction cost theory perspective}

After carrying out the logistics financial business, the third-party logistics companies act as the intermediate between banks and customers. On the one hand, it will help the clients needing funds to reduce the financing cost and ease the financing restrictions; on the other hand, it will help the banks to greatly reduce the cost of information collection and to avoid the like lihood of adverse selection of the clients needing funds. Under the business mode of logistic financial services, the goods of clients are usually under the monitor of third-party logistics companies, and the clients' transactions and the flow of goods are all under the supervision of third-party logistics companies, which can effectively reduce monitoring costs for the banks. In short, the development of logistics financial services can effectively reduce the financing transaction costs for the clients needing funds and information costs and monitoring costs for the banks.
IV. THE COMPARATIVE ADVANT AGES OF THE DEVELOPMENT OF LOGIST ICS FINANCE IN NINGBO CITY

A. The rapid economic growth relaying on Ningbo Port.

The development strategy of Ningbo City is "to thrive the city by relying on the port and to boost the port by relying on the city" (Cainan Wang, 2000) ${ }^{[3]}$. Nowadays, the development of Ningbo port has promoted economic prosperity of Ningbo City, and the development of economic induces to the development of port logistics, further causes the needs of financial services. So the economic prosperity of Ningbo City relaying on Ningbo port in turn will boost the development of logistics financial services until success.

\section{B. The rapid development of logistics industry.}

The logistics industry of Ningbo City is walking in the forefront of China from weak to strong. At present, Ningbo City has been acted as one of the cities included in the national logistics nodes cities in China, and there are nearly 4,000 logistics companies engaging in transportation, warehousing, freight forwarding, shipping industry and logistics business services (Xinshang Yin, 2009) ${ }^{[4]}$. What's more, the growth rate of the logistic enterprises exceeds $10 \%$ per year. So the rapid development of modern logistics industry would inevitably leads to the financing needs, which will inevitably provide greater living space for the development of logistics financial services in Ningbo City.

\section{High-level financial services.}

Ningbo City has played an very important role in the history of financial development in China. Ningbo City is also one of experimental cities of China's financial system reform, e-finance pilot cities, financial openness city and private equity pilot cities. The scale of the financial sector, development of financial market and the level of financial infrastructure in the Yangtze River Delta cities ranks the forefront (Xingshan Yin, 2008) ${ }^{[5]}$, and in the second phase of the "China Financial Centres Index (CFCI)" rating ranks No. 7 (China Development Institute, 2010) ${ }^{[6]}$. Meanwhile, Ningbo City has a very good financial environment and has always been the top three in recent years (Yang Li, Guogang Wang and Yuhui Liu, 2006) ${ }^{[7]}$. This provides Ningbo City a good basis for the development of modern logistics financial services.

\section{THE IDEA OF DEVELOPMENT MODE OF LOGIST ICS FINANCIAL SERVICES IN NINGBO CITY}

\section{A. Highlighting the core of logistics enterprises and carrying out the unified credit polices}

If a city wants to establish perfect logistics infrastructure, and multi-level interaction mechanisms of logistics development, the key is the mode innovation of the logistics financial services. At present, Ningbo City has many logistics companies with the characteristics of flexibility, efficient operation and adequate competition. Those professional third party logistics service providers include 
the domestic enterprises such as Sinotrans Zhejiang Co., Ltd, Zhongtong Logistics, Ningbo Daguang Container Co., Ltd and so on; also include foreign enterprises, such as FedEx Express, MAERSK LINE, UPS Express and other wellknown international logistics enterprises. Considering the advantages of supporting facilities and comparative advantages of logistics companies in Ningbo City, adopting a unified credit financing model maybe the best choice for the third party logistics enterprises. Unified credit mode means that the third-party logistics enterprises guarantee payback the load offering their credit standing as guarantee, then the banks provide the third-party logistics enterprises with a certain amount of money and the logistics companies can lend these credit funds to their clients. The merit of this modus is that banks basically do not participate in the process of project-specific loans and clearing operations.

\section{B. Optimizing credit mechanisms for small and medium sized commercial bank and building the professional logistics bank.}

In developed countries, logistics finance companies have become the main body of logistics financing market, which may offer the professional financial services for logistics enterprises. Take UPS express as an example, it may set up its own financial sector after the acquisition of First American International Bank(FIB). However, relative laws and regulation of China do not allow non-financial institutions to be engaged in involve in financial business. In this case, it is necessary to build the professional logistics bank which can provide the logistics companies with good financial services. The new logistics bank may carry out the following business:

\section{1) The pattern of inventory credit.}

About $90 \%$ of the short-term and the long-term loans of small and medium enterprises are secured by offering guarantee outside of China, such as the land or real estate and so on. However, considering the development history of domestic small and medium enterprises is too short to own a number of physical assets as mortgage, so they have to suffer the bottleneck constraints of credit because of short of mortgage. There are many ways in the west countries for mortgage financing, such as package inventory lien, open storage financing, warehouse storage financing, trust receipt financing and documents mortgage financing and so on. Unfortunately, there aren't the same ways for financing, so it is necessary to learn the good experience from the west countries and to carry out the business of inventory credit.

\section{2) The pattern of accounts receivable financing.}

The pattern of accounts receivable financing means that the logistics enterprises offer a certain accounts receivables as guarantees to borrow a certain a mount of money from the banks. The mortgage credit contract clearly stipulates that the third-party logistics companies may lend approximately $70 \%-80 \%$ of accounts receivable from financial institutions. In fact, the loan rate of the mortgage credit contract usually depends on the nature, quality of the accounts receivables acting as the pledge.

C. Drawing on the successful experience of UPS and establishing the company with logistics finance business

UPS express is one of the international express companies which provides logistics finance services, and its global supply chain finance solutions may help coordinate cargo flow, information flow and cash flow of the logistics enterprises in the world. The significant advantages and obvious features of UPS express is that the company does not only own the financial sector, but also can provide their clients with logistics services(Kai Zhang, 2008) ${ }^{[8]}$. The slogan of UPS express is that "achieving the process of synchronization of logistics flow, information flow and capital flow for their consumers". According to the investigation, the results show that there isn't professional logistics financial services company in Ningbo City. Therefore, it is necessary to build such enterprises as soon as possible.

\section{COUNTERMEASURES}

A. To accelerate cultivation and introduction of professionals concerning logistics financial services

Because of the shortage of the professionals concerning logistics financial services, the government authorities of Ningbo City should make great efforts to bring up them and introduce experts of logistics financial services into Ningbo City. Firstly, the Modern Logistics Training Base of Ningbo City may preside over professionals training; secondly, in the process of implementation of the "Introducing talents" project of Ningbo City, the government authorities should introduce the world's leading experts, academics and creative teams concerning logistics financial services into Ningbo City, these people are willing to work at Ningbo City through a series of preferential policies and fiscal support.

\section{B. To encourage innovation of logistics financial products in order to meet the needs of logistics development.}

Because the products concerning logistics financial services in Ningbo City are so lack that it cannot meet the increasingly diverse and individual financing needs, the third-party logistics enterprises and financial institutions both should strive to inaugurate financial services products and try their best to restructure and optimize the existing mode of logistics financial services, in order to meet the needs of clearing, payment functions, financing functions, resource allocation and agency consulting of modern logistics enterprises in Ningbo City.

C. To optimize the information platform of the development of logistics financial services.

Logistics, capital flow, information flow are the important for the development of modern logistics industry. Among these factors, information flow connects with the 
logistics and cash flow. Therefore, logistics information management is very important. Specific management approach of information flow is that: (1) through the official websites of logistics business, financial institutions, government authorities and the other channels to set up the information communication platform, and timely release all kinds of information to meet the needs of all parties. (2) by the government-led, multilateral cooperation to build specialized information processing platform and specialized transaction settlement systems. At present, the running fourth party logistics trading platform in Ningbo City meets some of these requirements, but it needs further standardization and normalization.

\section{To constitute credit system for SMEs and perfect the relative laws and regulations}

At present, relative credit legislation has not been perfect, the credit rating of the application, data collection and use of credit rating industry lacks legal basis. Therefore, the concerning government authorities should speed up the credit legislation, industry regulations as soon as possible. At the same time, the concerning department of government should pay close attention to build credit information databases of SMEs, and provide the clients with full angle of credit management, in order to ease the obvious contradictions of asymmetric information between banks and enterprises, and control the existence of various risks in the processes of logistics financial services.

\section{ACKNOWLEDGMENTS}

This work was financially supported by the Philosophy and Social Science Planning Project of Ningbo City (Grant No. G15-GJ02)

\section{REFERENCES}

[1] Qiong. Tianjin. Research on the development of logistics finace in Binhai New Area of Tianjin City [D]. a Master's Degree Thesis of Tianjin University, China, 2008.

[2] Yi hui Jiang. Study on innovation of logistics financial services[D].a Master's Degree of Xiangtan University, China,2008.

[3] Cainan Wang. Strengthening the Strategy of"To Thrive the City by Relying on the Port and to Boost the Port by Relying on the City" [J]. Journal of Ningbo University(Liberal Arts Edition),2000,Vol.13, issue 1, pp. 72-75.

[4] Xingshan Yin. Study on the stratages of the development of logistics finance and shipping finance in Ningbo City[P].Financial Times, November 23, 2009.

[5] Yin Xingshan. Research on financial services development take ningbo for example[D]. PhD thesis of Nanjing Agricultural University, China, 2008.

[6] China Development Institute(Shenzhen), China finance centre index report(Phase II)[R].2010.

[7] Yang Li, Guogang Wang, Yuhui Liu. Evaluation of financial ecological environment of Chinese cities[M].Beijing: People's Publishing House, 2005.

[8] Kai Zhang. Study on the logistics finance service innovation based on finance, transportation and warehous[D].PhD Dissertation of Chang' an University,China,2008. 